\title{
PERSPEKTIF FRAUD DIAMOND THEORY DALAM MENJELASKAN EARNINGS MANAGEMENT NON-GAAP PADA PERUSAHAAN TERPUBLIKASI DI INDONESIA
}

\author{
Bese Nur Amaliah \\ Universitas Sultan Ageng Tirtayasa \\ e-mail: besenuranaliah@gmail.com \\ Yeni Januarsi \\ Universitas Sultan Ageng Tirtayasa \\ e-mail: yenijanuarsi@gmail.com \\ Ewing Yufisa Ibrani \\ Universitas Sultan Ageng Tirtayasa \\ e-mail: ewing_ibrani@yahoo.com
}

\begin{abstract}
The purpose of this study is to investigate the cause factors of non-GAAP earnings management from Fraud Diamond Theory (FDT) perspective. FDT is a theory, which widely used in auditing area to explain the cause factors of fraud in companies. Using four FDT indicators, which are stress, opportunity, rationalization, and capabilities, this research investigates 42 companies from non-banking and non-financing industries during 2010 and 2013. As the results of logistic regression analyses, we find that opportunity and capabilities influence managers to conduct non-GAAP earnings management. On the other hand, stress and rationalization have the different results. The findings show that in Indonesia, opportunity and capabilities are two aspects that should be given a strong attention from Indonesian regulator in order to reduce non-GAAP earnings management.
\end{abstract}

Keywords: non-GAAP earnings management, Fraud Diamond Theory, restatement http://dx.doi.org/10.20885/jaai.vol19.iss1.art5

\begin{abstract}
Abstrak
Penelitian ini bertujuan untuk menyelidiki faktor-faktor penyebab manajemen laba non GAAP berdasarkan Fraud Diamond Theory (FDT). FDT merupakan teori yang banyak dipakai dalam bidang audit untuk menjelaskan faktor-faktor penyebab terjadinya kecurangan dalam perusahaan. Dengan menggunakan indikator-indikator FDT, yaitu tekanan, kesempatan, rasionalisasi dan kemampuan, penelitian ini menyelidiki 42 perusahaan bidang selain bank dan keuangan selama kurun waktu 2010 sampai dengan 2013. Sebagai hasil dari analisis regresi logistik, peneliti menemukan bahwa kesempatan dan kemampuan menjadi faktor penyebab terjadinya manajemen laba non-GAAP. Namun sebaliknya, tekanan dan rasionalisasi mempunyai hasil yang berbeda. Temuan-temuan dalam penelitian ini menunjukkan bahwa di Indonesia, faktor kesempatan dan kemampuan perlu mendapat perhatian lebih dari pembuat regulasi untuk mengurangi terjadinya manajemen laba non-GAAP.
\end{abstract}

Kata Kunci: non-GAAP earnings management, Fraud Diamond Theory, restatement

\section{PENDAHULUAN}

Banyaknya kasus manajemen laba yang terkuak ke permukaan serta rapuhnya sistem corporate goovernance menimbulkan keraguan atas integritas informasi yang disajikan kepada para investor (Rezaee 2002). Manajemen laba, seperti telah dinyatakan pada banyak literatur manajemen laba, dapat berbentuk 3 tipe yaitu 
(1) manajemen laba akrual, (2) manajemen laba riil, dan (3) manajemen laba non-GAAP. Tipe pertama dan kedua merupakan jenis earnings management yang masih dalam koridor prinsip akuntansi berterima umum (PABU), karena dilakukan dengan memanfaatkan fleksibilitas aturan-aturan akuntansi sedangkan tipe ketiga telah melanggar PABU. Di Indonesia, beberapa kasus manajemen laba Non-GAAP banyak terjadi. Sebagai contoh, kasus yang terjadi pada Bakrie Grup tahun 2010 dimana Indonesia Coruption Watch (ICW) melaporkan dugaan manipulasi pelaporan penjualan tiga perusahaan tambang batu bara milik Grup Bakrie kepada Direktorat Jenderal Pajak dan kasus diberikannya sanksi oleh Bursa Efek Indonesia (BEI) kepada empat emiten yaitu PT Bakrie \& Brother Tbk (BNBR), PT Bakrie Sumatra Plantations Tbk (UNSP), PT Energi Mega Persada Tbk (ENRG), dan PT Benakat Petroleum Energi Tbk (BIPI). Sanksi berupa denda masing-masing senilai Rp. 500 juta karena empat emiten tersebut terbukti memoles laporan keuangan melalui penyajian laba supaya tampak menguntungkan, dan berharap publik tertarik membeli saham mereka untuk meningkatkan harga saham (Kompas 2010).

Berdasarkan pra-investigasi yang dilakukan peneliti, kami mendokumentasikan beberapa kasus manajemen laba Non-GAAP yang terjadi di Indonesia pada Gambar 1. Dalam Gambar 1 terlihat bahwa selama 4 tahun terdapat 89 perusahaan yang melakukan penyajian kembali (restatement) laporan keuangan. Pada tahun 2011 dan 2012 terjadi peningkatan yang sangat drastis atas kasus manajemen laba tipe ini. Maraknya kasus managemen laba non-GAAP tersebut sangat mengkhawatirkan mengingat dampak negatif yang mungkin terjadi akibat managemen laba jenis ini sangat merugikan pihak perusahaan. Literatur manajemen laba telah mendokumentasikan banyak dampak negatif yang timbul akibat perilaku oportunis ini, seperti kemunduran dalam bisnis, tekanan untuk memenuhi harapan, solusi akuntansi yang dicoba, risiko terhitung dari auditor, skeptisme yang tidak mencukupi para pemakai laporan keuangan, investigasi hukum, dan hilangnya reputasi secara besar-besaran (Stice, Stice, dan Skousen 2004). Kerugian lainnya yang ditimbulkan oleh tindakan kecurangan tersebut adalah merugikan hubungan eksternal bisnis, semangat kerja karyawan, reputasi perusahaan, sehingga dalam jangka panjang dapat merugikan perusahaan (PWC 2003), serta pada beberapa kasus dapat menghancurkan nilai perusahaan (Badertscher 2011).

Pada jenis manajemen laba non-GAAP, jenis manajemen laba ini dapat dikatakan sebagai bentuk pelanggaran akuntansi yang paling buruk karena dapat mengarah pada kecurangan (fraud) laporan keuangan serta karena dilakukan di luar batas PABU dan dalam beberapa kasus dapat menghancurkan nilai perusahaan (Badertscher 2011). Hearly dan Wahlen (1999) menyatakan bahwa manajemen laba Non GAAP merupakan manajemen laba dapat mengarah kepada tindakan kecurangan (fraud).

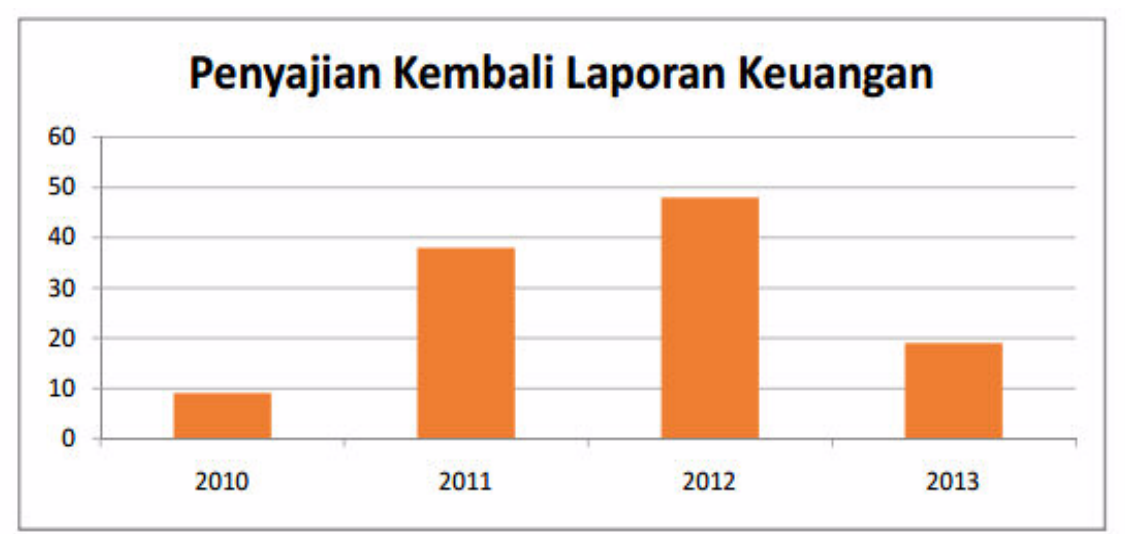

Gambar 1: Kasus Manajemen Laba Non-GAAP BerupaRestatement Laporan Keuangan 
Sebagian besar riset terdahulu dalam area manajemen laba difokuskan pada jenis manajemen laba akrual dan manajemen laba riil. Walaupun demikian, tidak banyak penelitian dalam literatur manajemen laba yang difokuskan pada jenis managemen laba nonGAAP, padahal jenis management laba ini merupakan jenis managemen laba yang paling buruk dan berpotensi melahirkan dampak buruk juga bagi kelangsungan operasional perusahaan. Oleh karena itu sangat penting dilakukan investigasi tentang penyebab manajemen laba jenis ini dapat terjadi.

Berbagai konsekuansi negatif potensial tersebut dan maraknya kasus manajemen laba Non-GAAP yang terjadi serta berdasarkan fakta yang telah kami sajikan sebelumnya menunjukkan bahwa sangat penting mengetahui penyebab mengapa menajemen laba non-GAAP dilakukan sehingga managemen laba jenis ini dapat diminimalisir dan kebijakkan yang diambil dapat disesuaikan dengan penyebab terjadinya perilaku tersebut.

Penelitian ini bertujuan untuk menguji determinan manajemen laba non-GAAP dari perspektif Fraud Diamond Theory (FDT), yang pada awalnya digunakan dalam bidang pengauditan untuk menjelaskan mengapa kecurangan dalam laporan keuangan dapat terjadi yang dipadukan dengan motivasi manajemen laba yang kemukakan oleh Scott (2012). Scott (2012) menyebutkan bahwa motivasi manajer untuk melakukan manajemen laba didasari oleh the bonus plan hypothesis, other contracting motivations, earning expectations and montain reputation, dan Initial Public Offering (IPO).

Kami berargumen bahwa FDT berpotensi untuk dapat menjelaskan mengapa manajemen laba non-GAAP dapat terjadi karena pada awalnya, dalam bidang pengauditan, FDT digunakan untuk menjelaskan motivasi-motivasi yang timbul atas tindakan kecurangan dalam laporan keuangan (fraud of financial reporting). Jika praktik manajemen laba non-GAAP secara konsep tidak diragukan lagi dapat mengarah kepada kecurangan laporan keuangan, berarti bahwa manajemen laba non-GAAP sangat dekat dengan kecurangan atas laporan keuangan, sehingga setiap motivasi yang timbul untuk melakukan fraud secara potensial dapat juga memotivasi untuk dilakukannya manajemen laba non-GAAP.

Dalam perspektif FDT, terdapat empat elemen penting yang digunakan untuk menjelaskan mengapa manajemen laba non-GAAP berpotensi terjadi. Keempat elemen tersebut adalah (1) tekanan/motif manajemen, (2) kesempatan, (3) rasionalisasi, dan (4) kapabilitas. Elemen pertama, tekanan merupakan situasi dimana manajemen merasakan insentif atau tekanan untuk melakukan manajemen laba. Tekanan dapat mencakup hampir semua hal, termasuk hal keuangan dan non keuangan. Dalam hal keuangan, tekanan dapat terjadi saat manajemen sedang membutuhkan uang untuk memenuhi kebutuhan pribadinya misalnya tekanan untuk biaya pengobatan, tekanan dari keluarga yang menuntut keberhasilan secara ekonomi, serta pola hidup mewah (Rustendi 2009). Sedangkan dalam hal non keuangan, tekanan dapat terjadi saat manajemen melakukan tindakan untuk menutupi kinerja yang buruk karena tuntutan perkerjaan untuk mendapatkan hasil yang baik. Moeller (2009) mengemukakan bahwa tekanan situasi berpotensi muncul karena adanya kewajiban keuangan yang melebihi batas kemampuan yang harus diselesaikan manajemen, dan terjadi kegagalan hubungan kerja antara perusahaan dengan pegawainya, baik yang berkenaan dengan akses terhadap penggunaan aktiva perusahaan, kompensasi yang tidak sesuai dengan harapan, maupun jenjang karir manajemen yang tidak jelas.

Elemen kedua, kesempatan yaitu adanya atau tersedianya kesempatan untuk melakukan manajemen laba atau situasi yang membuka kesempatan bagi manajemen untuk melakukan manajemen laba. Kesempatan akan timbul pada saat sistem pengelolaan yang masih rapuh pada badan usaha dan pengendalian internal perusahaan yang lemah serta melalui penggunaan posisi (Gagola 2011). Hal tersebut menimbulkan banyak celah yang menjadikan kesempatan bagi manajemen untuk 
memanipulasi transaksinya dengan melakukan manajemen laba untuk kepentingan pribadi maupun kepentingan perusahaan.

Elemen ketiga, rasionalisasi dapat diartikan sebagai adanya atau munculnya sikap, karakter, atau serangkaian nilai-nilai etis yang membolehkan manajemen atau pegawai untuk melakukan tindakan yang tidak jujur. Rendahnya integritas yang dimiliki seseorang menimbulkan pola pikir dimana orang tersebut merasa dirinya benar saat melakukan kecurangan, sebagai contoh manajemen membenarkan untuk melakukan praktik manajemen laba Non GAAP. Penyimpangan yang dilakukan manajemen juga disebut dengan moral hazard problem. Moeller (2009) menyatakan bahwa banyaknya praktik kecurangan yang terjadi di perusahaan menjadi salah satu pemicu manajemen untuk melakukan hal yang sama, contohnya melakukan praktik manajemen laba dan menganggapnya hal yang biasa dilakukan.

Elemen keempat, Kapabilitas yaitu seberapa besar daya dan kapabilitas dari seseorang itu melakukan kecurangan (fraud) di lingkungan perusahaan. Wolfe dan Hermanson (2004) menyatakan banyak kecurangan (fraud) yang umumnya bernominal besar tidak mungkin terjadi apabila ada orang tertentu dengan kapabilitas khusus yang ada dalam perusahaan.

Berdasarkan FDT, kami berasumsi bahwa manajer dapat melakukan manajemen laba Non GAAP apabila terdapat kesempatan yang merupakan pintu masuk bagi dilakukannya manajemen laba tipe tersebut, mendapatkan tekanan dan munculnya sikap rasionalisasi yang mendorong untuk melakukan manajemen laba Non GAAP, serta memiliki kapabilitas yang tinggi dalam mengotak-atik laba yang diinginkan, sehingga keempat situasi potensial (adanya kesempatan, tekanan, rasionalisasai, dan kapabilitas) tersebut dapat digunakan manajer untuk mengejar kepentingan pribadinya dan jika dibiarkan dalam jangka panjang akan memiliki dampak yang merugikan perusahaan dan seluruh pengguna laporan keuangan.

Penelitian ini penting untuk dilakukan karena beberapa hal. Pertama, penelitian ini diharapkan dapat menunjukkan penyebab mengapa manajemen laba Non GAAP dilakukan oleh manajer berdasar pada suatu teori yang telah establish, yaitu Fraud Diamond Theory (FDT). Penelitian yang menguji dan menghubungkan FDT dengan manajemen laba non GAAP, sepenjang pengetahuan peneliti, belum pernah dilakukan sebelumnya. Kedua, diharapkan penelitian ini dapat memetakan solusi potensial untuk mengurangi manajemen laba Non GAAP, sehingga kualitas laporan keuangan dapat ditingkatkan. Ketiga, penelitian ini memberikan kontribusi penting dalam literatur manajemen laba dengan menunjukkan bahwa teori yang berasal dari bidang lan (dalam hal ini bidang auditing) dapat dikolaborasikan dengan bidang akuntansi keuangan demi mendapatkan penjelasan yang memadai dan ilmiah mengapa perilaku oportunis manajer, yaitu dilakukannya manajemen laba non GAAP dapat terjadi.

\section{TINJAUAN PUSTAKA DAN PERUMUSAN HIPOTESIS}

\section{Tekanan dan Manajemen Laba Non GAAP}

Tekanan merupakan situasi dimana manajemen merasakan insentif atau termotivasi untuk melakukan manajemen laba. Tekanan dapat terjadi pada manajemen mencakup hampir semua hal, termasuk hal keuangan dan non keuangan (Cressey 1953). Tekanan manajemen untuk memenuhi kebutuhan keuangan pribadinya menjadi faktor pemicu untuk melakukan manajemen laba Non GAAP yaitu dengan meningkatkan laba perusahaan sehingga porsi dividen yang akan dihasilkan juga cenderung lebih besar. Kinerja perusahaan yang buruk juga menjadi tekanan pada manajemen karena akan berdampak pada kurangnya aliran dana yang masuk ke dalam perusahaan, terutama dana yang didapatkan dari para investor potensial. Namun semakin banyak aliran dana yang masuk dalam perusahaan tentunya semakin banyak pula beban yang ditanggung manajemen untuk melunasi hutang perusahaan.

Achmad et al. (2007) menunjukkan 
bahwa peningkatan motivasi perjanjian hutang (debt covenant) meningkatkan praktik manajemen laba. Dengan demikian, perusahaan yang mempunyai rasio leverage yang tinggi, dimana hutangnya lebih tinggi dibandingkan dengan proporsi aktivanya akan cenderung melakukan manipulasi dalam bentuk manajemen laba Non GAAP yang dilakukan diluar batas GAAP. Apabila perusahaan memiliki leverage yang tinggi, berarti perusahaan itu memiliki hutang yang besar dan risiko kredit yang dimiliki juga tinggi. Perusahaan yang memiliki risiko kredit yang tinggi, cenderung tidak mampu untuk mengembalikan pinjaman modal yang diberikan. Oleh karena itu, perusahaan harus menyelamatkan diri dari kondisi yang demikian agar tetap dianggap mampu untuk mengembalikan pinjaman. Hal ini juga didukung oleh pendapat Skousen et al. (2009) yang berpendapat bahwa salah satu tekanan yang sering dialami manajemen perusahaan adalah kebutuhan untuk mendapatkan tambahan utang atau sumber pembiayaan eksternal agar tetap kompetitif, termasuk pembiayaan riset dan pengeluaran pembangunan atau modal. Dechow et al. (1996) berpendapat bahwa perusahaan dengan leverage yang tinggi akan memotivasi tindakan manipulasi laba. Penelitian yang dilakukan Aghghaleh et al. (2014) membuktikan bahwa leverage berpengaruh positif terhadap terjadinya kecurangan. Widyaningdyah (2001) dalam penelitiannya menemukan bahwa leverage berpengaruh positif dan signifikan terhadap manajemen laba. Berdasarkan argumen di atas, maka hipotesis pertama untuk proksi tekanan yang diajukan penulis adalah:

H1a: Leverage berpengaruh positif terhadap Manajemen Laba Non GAAP

Kepemilikan manajerial dapat dilihat dari ada tidaknya kepemilikan saham oleh orang dalam. Kepemilikan saham oleh orang dalam ini dianggap dapat mengatasi permasalahan agensi yang selama ini sering terjadi, sebab dengan adanya kepemilikan saham oleh orang dalam ini akan menyejajarkan kepentingan manajemen dan pemegang saham
(Rahmanti 2013). Kepentingan dari prinsipal adalah memperoleh deviden setinggitingginya yang dapat dilihat dari perolehan laba yang dihasilkan perusahaan, sedangkan kepentingan dari manajemen adalah mendapatkan kompensasi yang besar atas hasil kerjanya. Dengan adanya sebagian saham yang dimiliki oleh eksekutif perusahaan akan mempengaruhi kebijakan manajemen yang dibuat dalam mengungkapkan kinerja keuangan perusahaan. Dan dengan adanya kepemilikan ini, para manajer akan mendapat tekanan untuk bersikap hati-hati dalam menyajikan laporan keuangan dan lebih bersemangat dalam meningkatkan nilai perusahaan serta dapat memotivasi manajer untuk bekerja sesuai dengan kepentingan prinsipal. Para manajer juga akan merasa seperti memiliki perusahaan, sebab segala tindakan yang mereka lakukan diperusahaan dalam hal kebijakan manajerial, akan mempengaruhi deviden yang akan diterimanya. Dengan kata lain, perusahaan dengan komposisi pemilik saham sebagaian berasal dari orang dalam cenderung untuk tidak melakukan manajemen laba Non GAAP karena dalam beberapa kasus dapat menghancurkan nilai perusahaan (Badertscher 2011). Dalam penelitian Skousen et al. (2009) telah dibuktikan bahwa semakin tinggi persentase kepemilikan saham yang dimiliki orang dalam, maka probabilitas terjadinya kecurangan. Ujiyantho dan Pramuka (2007) menyatakan bahwa kepemilikan manajerial berpengaruh negatif dan signifikan terhadap manajemen laba. Berdasarkan argumen di atas, maka hipotesis kedua untuk proksi tekanan yang diajukan penulis adalah:

H1b: Kepemilikan manajerial berpengaruh negatif terhadap Manajemen Laba Non GAAP

Dalam menjalankan kinerjanya, manajer perusahaan dituntut untuk melakukan performa terbaik sehingga dapat mencapai target keuangan yang telah direncanakan. Perbandingan laba terhadap jumlah aktiva atau Return on Asset adalah ukuran kinerja operasional yang banyak digunakan untuk menunjukan seberapa 
efisien aktiva telah bekerja (Skousen et al. 2009). ROA sering digunakan dalam menilai kinerja manajer dan dalam menentukan bonus, kenaikan upah, dan lain-lain. Return on Asset (ROA) digunakan untuk mengukur kemampuan manajemen perusahaan dalam memperoleh keuntungan (laba) secara keseluruhan. Semakin besar ROA yang diperoleh, semakin besar pula tingkat keuntungan yang dicapai oleh perusahaan tersebut dan semakin baik pula posisi perusahan tersebut dari segi penggunaan aset (Dendawijaya 2005). Oleh karena itu, semakin tinggi ROA yang ditargetkan perusahaan maka semakin rentan perusahaan akan melakukan manajemen laba. Semakin besar ROA juga akan mempengaruhi investor dalam memprediksi laba dan memprediksi risiko dalam investasi sehingga memberikan dampak pada kepercayaan investor terhadap perusahaan. Hal tersebut akan membuat manajemen termotivasi untuk melakukan praktik manajemen laba Non GAAP agar dapat menarik dan meningkatkan kepercayaan investor tersebut.

Penelitian Carlsn dan Bathala (1997) membuktikan bahwa perusahaan yang memiliki laba yang besar (diukur dengan profitabilitas atau ROA) lebih mungkin melakukan manajemen laba daripada perusahaan yang memiliki laba yang kecil. Budiasih (2009) menyatakan profitabilitas yang diproksikan dengan variabel ROA berpengaruh positif terhadap manajemen laba. Berdasarkan argumen di atas, maka hipotesis ketiga untuk proksi tekanan yang diajukan penulis adalah:

H1c: ROA berpengaruh positif terhadap Manajemen Laba Non GAAP

\section{Kesempatan dan Manajemen Laba Non GAAP}

Kesempatan yaitu adanya atau tersedianya kesempatan untuk melakukan manajemen laba atau situasi yang membuka kesempatan bagi manajemen melakukan manajemen laba. Kesempatan akan timbul saat pengendalian internal perusahaan lemah (Gagola 2011). Kelemahan pengendalian internal memberi kesempatan bagi manajemen untuk memani- pulasi transaksi dengan melakukan manajemen laba Non GAAP dengan memperhitungkan pendapatan dilakukan di luar batas GAAP. Adanya informasi yang terjadi antara pemilik perusahaan selaku prinsipal dan manajemen selaku agen juga bisa menjadi sebuah kesempatan untuk melakukan tindakan-tindakn yang hanya mementingkan kepentingan mereka sendiri. Agen bisa melakukan tindakan yang tidak menguntungkan prinsipal secara keseluruhan yang dalam jangka panjang bisa merugikan kepentingan dari perusahaan tersebut. Untuk menghindari tindak kecurangan adanya praktik manajemen laba Non GAAP yang dilakukan manajemen, dibutuhkan unit pengawas yang mampu memonitoring jalannya perusahaan.

Pamudji dan Trihartati (2008) mem buktikan bahwa perusahaan dengan komite audit yang independen cenderung tidak melakukan kecurangan dengan melakukan praktik manajemen laba, karena komite audit memiliki fungsi pengawasan untuk menjamin bahwa manajemen melakukan tugasnya dengan baik. Komite audit bertanggung jawab untuk mengawasi laporan keuangan, mengawasi audit eksternal, dan mengamati sistem pengendalian internal (termasuk audit internal) dapat mengurangi sifat opportunistic manajemen yang melakukan manajemen laba dengan cara mengawasi laporan keuangan dan melakukan pengawasan pada audit eksternal (Sam'ani 2008).

Komite audit meningkatkan integritas dan kredibilitas pelaporan keuangan melalui; (1) pengawasan atas proses pelaporan termasuk sistem pengendlian internal dan prinsip akuntansi berterima umum; (2) mengawasi proses audit secara keseluruhan (Wardhani 2006). Hasilnya mengndikasika $n$ bahwa adanya komite audit memiliki konsekuensi pada laporan keuangan yaitu: (a) berkurangnya pengukuran akuntansi yang tidak tepat; (b) berkurangnya tindakan kecurangan manajemen dan tindakan ilegal. Dari penjelasan tersebut dapat disimpulkan bahwa komite audit dapat mengurangi aktivitas manajemen laba Non GAAP yang dampaknya dalam jangka 
panjang dapat merugikan perusahaan dan seluruh pemakai laporan keuangan. Sehingga untuk menguji pengaruh kesempatan terhadap manajemen laba Non GAAP, maka kesempatan dalam penelitian ini menggunakan proxy yaitu presentase komite audit independen, jumlah komite audit, dan jumlah pertemuan antar anggota komite audit (Skousen et al. 2009).

Independensi merupakan karakteristik terpenting yang harus dimiliki oleh komite audit untuk memenuhi peran pengawasannya. Hal tersebut menjelaskan mengapa bursa efek mengeluarkan undang-undang dan peraturan yang berkaitan dengan independensi komite audit. BRC (1999) merekomendasikan bahwa komite audit seharusnya hanya terdiri dari komisaris yang tidak mempunyai hubungan dengan perusahaan yang mungkin akan merusak independensinya. Penelitian yang dilakukan oleh Skousen et al. (2009) membuktikan bahwa proporsi anggota komite audit independen berpengaruh negatif terhadap kecurangan laporan keuangan. Pamudji dan Trihartati (2008) membuktikan bahwa independensi komite audit secara signifikan berpengaruh negatif terhadap tingkat manajemen laba. Berdasarkan argumen di atas, maka hipotesis pertama untuk proksi kesempatan yang diajukan penulis adalah:

H2a : Komite Audit Independen berpengaruh negatif terhadap Manajemen Laba Non GAAP

Securities and Exchange Commission (SEC) menghendaki bahwa setiap komite audit harus terdiri dari minimal satu anggota yang merupakan ahli keuangan. Hal tersebut juga disyaratkan oleh Bapepam (2004). Pembentukan dan Pedoman Pelaksanaan Komite Audit Nomor IX.I.5 menurut BAPEPAM mengenai keanggotaan komite audit merekomendasikan adanya minimal satu anggota komite audit yang memiliki keahlian akuntansi atau keuangan dengan asumsi bahwa anggota tersebut dapat meningkatkan keefektifan kinerja. Keahlian di bidang keuangan sama pentingnya bagi komite audit karena fungsi utama dari komite audit tersebut adalah mengawasi proses pelaporan keuangan sebuah perusahaan (Rahman dan Ali 2006). Ahli finansial dengan pengetahuan dan keahlian tertentu, diharapkan dapat memandu anggota komite audit lainnya untuk mengidentifikasi pertanyaan yang dapat memberi tantangan pada manajemen dan audit eksternal, serta dapat meningkatkan kualitas laporan keuangan sehingga akan terjadi hubungan negatif antara keahlian keuangan yang dimiliki komite audit dengan kecurangan laporan keuangan, dengan melakukan praktik manajemen laba Non GAAP yang dalam beberapa kasus dapat menghancurkan nilai perusahaan dan hilang nya reputasi perusahaan secara besar-besaran (Baderstcher 2011).

Penelitian yang dilakukan oleh Skousen et al. (2009) membuktikan bahwa keahlian keuangan yang dimiliki komite audit berpengaruh negatif terhadap kecurangan laporan keuangan. Xie et al. (2003) dan Choi et al. (2004) menyatakan bahwa anggota komite audit yang merupakan komisaris independen yang ahli di bidang akuntansi merupakan efektif untuk mengurangi manajemen laba. Berdasarkan argumen di atas, maka hipotesis kedua untuk proksi kesempatan yang diajukan penulis adalah:

H2b: Keahlian komite audit di bidang keuangan berpengaruh negatif terhadap Manajemen Laba Non GAAP

Semakin banyak jumlah anggota komite audit akan semakin meningkatkan efektivitas pengawasan sehingga manajemen tidak memiliki kesempatan untuk melakukan kecurangan dengan melakukan praktik manajemen laba Non GAAP yang dampaknya akan menghancurkan nilai perusahaan dan dalam jangka panjang dapat merugikan perusahaan serta seluruh pemakai laporan keuangan. Penelitian yang dilakukan Aghghaleh et al. (2014) membuktikan bahwa jumlah anggota komite audit berpengaruh negatif terhadap terjadinya kecurangan. Penelitian yang dilakukan oleh Skousen et al. (2009) membuktikan bahwa jumlah anggota komite audit ber- 
pengaruh negatif terhadap kecurangan laporan keuangan. Berdasarkan argumen di atas, maka hipotesis ketiga untuk proksi kesempatan yang diajukan penulis adalah:

H2c: Jumlah anggota komite audit berpengaruh negatif terhadap Manajemen Laba Non GAAP

Semakin banyak pertemuan yang dilakukan oleh para komite audit maka semakin efektif pula pengawasan yang dilakukan, sehingga kesempatan untuk melakukan manajemen laba Non GAAP yang dilakukan manajemen dapat diminimalisir. Abbot et al. (2004) membuktikan bahwa perusahaan dengan komite audit yang mengadakan pertemuan minimal empat kali dalam setahun cenderung tidak melakukan manajemen laba Non GAAP laporan keuangan sehingga akan terjadi hubungan yang negative antara jumlah rapat tahunan komite audit dengan kecurangan laporan keuangan. Penelitian yang dilakukan oleh Skousen et al. (2009) membuktikan bahwa jumlah rapat tahunan komite audit berpengaruh negatif terhadap kecurangan laporan keuangan. Xie et al. (2003) membuktikan bahwa jumlah pertemuan antar anggota komite audit berhubungan negative dengan tingkat manajemen laba. Berdasarkan argumen di atas, maka hipotesis keempat untuk proksi kesempatan yang diajukan penulis adalah:

H2d : Jumlah pertemuan antar anggota komite audit berpengaruh negative terhadap Manajemen Laba Non GAAP

\section{Rasionalisasi dan Manajemen Laba Non GAAP}

Rasionalisasi dapat diartikan sebagai adanya atau munculnya sikap, karakter, atau serangkaian nilai-nilai etis yang membolehkan manajemen atau pegawai untuk melakukan tindakan yang tidak jujur. Cressey, D. R (1953) menjelaskan rasionalisasi sebagai pemikiran yang menjustifikasi tindakannya sebagai suatu perilaku yang wajar, yang secara moral dapat diterima dalam suatu masyarakat yang normal. Rasionalisasi lebih sering dihubungkan dengan sikap dan karater sese- orang yang membenarkan nilai-nilai etis yang sebenarnya tidak baik (Rustendi 2009). Rendahnya integritas yang dimiliki seseorang menimbulkan pola pikir dimana orang tersebut merasa dirinya benar saat melakukan kecurangan, dimana manajemen membenarkan untuk melakukan praktik manajemen laba Non GAAP. Penyimpangan yang dilakukan manajemen juga disebut dengan moral hazard problem. Moeller (2009) menyatakan bahwa banyaknya praktik kecurangan yang terjadi di perusahaan menjadi salah satu pemicu manajemen untuk melakukan hal yang sama, contohnya melakukan praktik manajemen laba Non GAAP dan menganggapnya hal yang biasa dilakukan.

Keterkaitan antara integritas manajemen dengan risiko audit seperti yang diungkapkan Turner et al. (2003) memiliki hubungan terbalik. Manajemen yang memiliki inte gritas tinggi akan berdampak pada kecilnya risiko audit. Jika integritas yang dimiliki manajemen rendah maka risiko audit yang ditimbulkan akan besar. Semakin kecil integritas manajemen maka semakin besar pula tingkat rasionalisasi yang dimiliki manajemen. Francis and Krishnan (1999) menyimpulkan bahwa kelebihan dari penggunaan diskresionari akrual dari praktik manajemen laba akan menyebabkan opini audit tidak wajar. Tindakan manajemen laba tersebut tentunya karena manajemen merasionalisasikan perbuatannya. Penelitian yang dilakukan oleh Skousen et al., (2009) membuktikan bahwa opini audit berpengaruh negatif terhadap kecurangan laporan keuangan. Berdasarkan argumen di atas, maka hipotesis yang diajukan penulis adalah:

H3: Opini audit berpengaruh negatif terhadap Manajemen Laba Non GAAP

\section{Kapabilitas dan Manajemen Laba Non GAAP}

Kapabilitas adalah suatu faktor kualitatif yang menurut Wolfe dan Hermanson (2004) merupakan salah satu pelengkap dari model fraud triangle yang dikemukakan oleh Cressey (1953). Kapabilitas yaitu seberapa besar daya 
dan kemampuan dari seseorang itu melakukan kecurangan (fraud) di lingkungan perusahaan. Seperti contoh manajer dapat melakukan manajemen laba Non GAAP apabila memiliki kapabilitas, sehingga manajemen tersebut dapat melakukan apapun untuk kepentingan pribadinya tetapi dalam jangka panjang akan memiliki dampak yang merugikan perusahaan dan seluruh pengguna laporan keuangan. Dalam penelitian ini digunakan perubahan direksi sebagai proksi dari kapabilitas.

Wolfe dan Hermanson (2004) meneliti tentang kapabilitas sebagai salah satu fraud risk factor yang melatarbelakangi terjadinya kecurangan (fraud) dan menyimpulkan bahwa perubahan direksi dapat mengindikasikan terjadinya fraud. Perubahan direksi pada umumnya sarat dengan muatan politis dan kepentingan pihak-pihak tertentu yang memicu munculnya conflict of interest. Perubahan direksi tidak selamanya berdampak baik bagi perusahaan. Perubahan direksi bisa menjadi suatu upaya perusahaan untuk memperbaiki kinerja direksi sebelumnya dengan melakukan perubahan susunan direksi ataupun perekrutan direksi yang baru yang dianggap lebih berkompeten dari direksi sebelumnya. Sementara disisi lain, pergantian direksi bisa jadi merupakan upaya perusahaan untuk menyingkirkan direksi yang dianggap mengetahui fraud yang dilakukan perusahaan serta perubahan direksi dianggap akan membutuhkan waktu adaptasi sehingga kinerja awal tidak maksimal.

Kompleksitas dan ketidakstabilan struktur organisasi perusahaan ditandai dengan tingginya perputaran posisi manajer senior, konsultan, dan jajaran direksi (Skousen et al. 2009). Adanya pergantian struktur jajaran direksi biasanya diikuti dengan praktik manajemen laba karena mendekati masa jabatannya manajemen akan memaksimalkan bonus akhir tahun. Manajemen laba khususnya manajemen laba Non GAAP merupakan cara akhir yang dilakukan manajemen pada saat manajemen tidak bisa mencapai target perusahaan yang berdampak pada pergeseran jabatan. Penelitian yang dilakukan oleh Wolfe dan Hermanson (2004) menyatakan bahwa peru- bahan direksi dapat mengindikasi terjadinya kecurangan (fraud). Skousen et al. (2009) membuktikan bahwa perubahan direksi berpengaruh positif terhadap kecurangan laporan keuangan dengan melakukan praktik manajemen laba. Berdasarkan argumen di atas kapabilitas dalam penelitian ini menggunakan proksi perubahan direksi, maka hipotesis yang diajukan penulis adalah:

H4: Perubahan direksi berpengaruh positif terhadap Manajemen Laba Non GAAP

\section{METODA PENELITIAN}

\section{Populasi dan Sampel}

Populasi dalam penelitian ini adalah seluruh perusahaan yang terdaftar di Bursa Efek Indonesia pada tahun 2010 sampai dengan tahun 2013. Penelitian ini dilakukan pada tahun 2010-2013 dikarenakan pada tahun tersebut terjadi peningkatan berbagai skandal dan kecurangan akuntansi terkait kasus-kasus manipulasi manajemen laba Non GAAP dan juga agar dapat memberikan gambaran terbaru mengenai kasus manipulasi yang dialami perusahaan publik di Indonesia saat ini.

Sampel yang digunakan dalam penelitian ini adalah perusahaan non keuangan dan non perbankan yang terdaftar di Bursa Efek Indonesia selama periode tahun 2010 sampai 2013 dengan kriteria tertentu. Metode pengambilan sample yang akan digunakan adalah metode purposive sampling berdasarkan kriteria sebagai berikut: Perusahaan yang menyajikan laporan tahunannya dalam website perusahaan atau website BEI selama periode 2010-2013: Perusahaan yang menyajikan kembali (restatement) laporan keuangan sebagai proksi indikasi terjadinya manajemen laba Non GAAP selama periode 2010-2013; Perusahaan yang melakukan penyajian kembali (restatement) laporan keuangan disebabkan karena kesalahan mendasar yang terdaftar di Bursa Efek Indonesia selama periode 20102013. Laporan tahunan perusahaan memiliki data-data yang lengkap berkaitan dengan variabel penelitian; dan laporan keuangan yang disajikan dalam bentuk mata uang rupiah. 


\section{Pengukuran Variabel}

Variabel dependen dalam penelitian ini adalah Manajemen Laba Non GAAP. Dalam penelitian ini, manajemen laba Non GAAP diukur dengan menggunakan variabel dummy dengan kategori 1 untuk perusahaan yang menyajikan kembali laporan keuangan (restatement) pada periode 2010-2013, dan kategori 0 untuk sebaliknya (Badertscher 2011). Perusahaan yang dikategorikan melakukan penyajian kembali laporan keuangan (restatement) adalah perusahaan yang melakukan restatement yang diakibatkan karena kesalahan mendasar, bukan disebabkan karena penggabungan bisnis (merger atau akuisisi), perubahan estimasi akuntansi dan perubahan kebijakan akuntansi akibat konvergensi atau penerapan Pernyataan Standar Akuntansi Keuangan (PSAK) atau International Financial Reporting Standard (IFRS). Penyajian kembali adalah hasil dari manajemen laba dimana terjadi pendapatan yang meningkat dikarenakan kesalahan pelaporan akuntansi (Badertscher 2011).

\section{Tekanan}

Tekanan merupakan situasi dimana manajemen merasakan insentif atau tekanan untuk mełkukan manajemen laba. Tekanan dalam penelitian ini diproksikan oleh Leverage (LEV), Kepemilikan Manajerial (OSHIP), dan Return On Asset (ROA) (Skousen et al, 2009).

Leverage (LEV) yaitu rasio yang digunakan untuk mengukur seberapa jauh aktiva perusahaan dibiayai dengan hutang atau dibiayai oleh pihak luar. Kemampuan untuk mendapatkan pinjaman dari luar perusahaan serta kemapuan untuk membayar pinjaman tersebut dianggap sebagai tekanan yang bersumber dari faktor eksternal. Leverage sebagai proxy tekanan eksternal di mana leverage yang tinggi akan menimbulkan tekanan pada manajemen sehingga menyebabkan manajemen melakukan manajemen laba. Leverage dihitung dengan membagi total hutang dengan total (Skousen et al. 2009).

Kepemilikan Manajerial (OSHIP) yaitu komposisi saham yang dimiliki manajemen di dalam perusahaan. Skousen et al. (2009) mengindisikan saat eksekutif memiliki porsi kepemilikan di dalam perusahaan, maka situasi keuangan pribadi mereka juga akan dipengaruhi oleh kondisi keuangan perusahaan. Tekanan manajemen untuk memenuhi kebutuhan keuangan pribadinya menjadi faktor pemicu untuk melakukan kecurangan dengan meningkatkan atau memanipulasi laba perusahaan sehingga porsi deviden yang akan dihasilkan juga cenderung lebih besar. OSHIP dihitung dengan membagi total saham yang dimiliki oleh pihak manajemen dengan total saham biasa yang beredar (Skousen et al. 2009).

Return On Asset (ROA) yaitu rasio yang digunakan untuk mengukur kemampuan manajemen perusahaan dalam memperoleh keuntungan (laba) secara keseluruhan. ROA sering digunakan dalam menilai kinerja manajer dan dalam menentukan bonus, kenaikan upah, dan lain-lain. Laba yang besar akan menarik investor karena perusahaan memiliki tingkat pengembalian yang semakin tinggi. Penelitian Carlsn dan Bathala (1997) membuktikan bahwa perusahaan yang memiliki laba besar (diukur dengan profitabilitas atau ROA) lebih mungkin melakukan manajemen laba daripada perusahaan yang memiliki laba yang kecil. ROA dihitung dengan membagi laba bersih dengan total asset (Skousen et al. 2009)

\section{Kesempatan}

Kesempatan merupakan adanya atau tersedianya kesempatan untuk melakukan manajemen laba atau situasi yang membuka kesempatan bagi manajemen untuk melakukan manajemen laba. Kesempatan dalam penelitian ini diproksikan oleh komite audit independen (AUDCIND), jumlah komite audit (AUDSIZE), dan jumlah rapat tahunan komite audit (AUDCMEET) (Skounsen et al. 2009). AUDCIND dihitung dengan membagi jumlah anggota komite, AUDCSIZE diukur dengan menggunakan jumlah anggota komite audit, (Skousen et al. 2009) sedangkan AUDCMEET diukur dengan menggunakan Jumlah pertemuan antar anggota komite audit yang dilakukan dalam satu tahun (Skousen et al. 2009). 


\section{Rasionalisasi}

Rasionalisasi dapat diartikan sebagai adanya atau munculnya sikap, karakter, atau serangkaian nilai-nilai etis yang membolehkan manajemen atau pegawai untuk melakukan tindakan yang tidak jujur. Cressey (1953) menjelaskan rasionalisasi sebagai pemikiran yang menjustifiksi tindakannya sebagai suatu perilaku yang wajar, yang secara moral dapat diterima dalam suatu masyarakat normal. Rasionalisasi dalam penelitian ini diproksikan oleh opini audit (AUDREPORT). Francis and Krishnan (1999) menyimpulkan bahwa kelebihan dari penggunaan diskresionari akrual yaitu merupakan salah satu praktik manajemen laba menyebabkan opini audit tidak wajar. Tindakan manajemen laba tersebut dikarenakan manajemen merasionalkan perbuatannya. AUDREPORT diukur dengan menggunakan variabel dummy (Skousen et al. 2009). AUDREPORT: Kategori 1 jika perusahaan menerima opini wajar tanpa pengecualian (qualified) dan kategori 0 jika perusahaan menerima opini lain selain opini wajar tanpa pengecualian (unqualified)

\section{Kapabilitas}

Kapabilitas artinya seberapa besar daya dan kapabilitas dari seseorang itu melakukan kecurangan (fraud) di lingkungan perusahaan. Kapabilitas dalam penelitian ini diproksikan oleh keahlian anggota komite audit di bidang keuangan (AUDCEXP). Keahlian anggota komite audit di bidang keuangan dapat dilihat dari latar belakang pendidikan anggota komite audit di bidang akuntansi atau keuangan atau pernah menduduki posisi penting dibidang keuangan dalam suatu organisasi. AUDCEXP diukur dengan menggunakan variabel dummy yaitu jika jumlah anggota komite audit yang meihiki latar belakangpendidikan anggota komite audit di bidang akuntansi atau keuangan atau pernah menduduki posisi penting dibidang keuangan dalam suatu organisasi, diberi nilai 1. Jika tidak memenuhi syarat tersebut diberi nilai nol (Skousen et al. 2009).

\section{Variabel Kontrol}

Variabel kontrol adalah variabel yang dikendalikan atau dibuat konstan sehingga hubungan variabel independen terhadap variabel dependen tidak dipengaruhi faktor luar yang tidak diteliti (Sugiyono 2013). Variabel kontrol yang digunakan dalam penelitian ini adalah ukuran perusahaan (SIZE) yang diukur dari jumlah total asset yang dimiliki oleh perusahaan, Return on Equity (ROE) yang diukur dari perbandingan antara laba bersih perusahaan dengan modal sendiri atau total ekuitas, dan auditor type (BIG 4) yang diukur dengan menggunakan variabel dummy jika perusahaan diaudit oleh Big 4 auditor diberi katagori 1, dan kategori 0 jika sebaliknya yang digunakan oleh (Baderstscher 2011).

\section{Pengujian Hipotesis}

Pengujian hipotesis dalam penelitian ini adalah dengan menggunakan regresi logistik. Model ini dipilih dengan alasan bahwa data yang digunakan dalam penelitian ini bersifat non metrik pada variabel dependen (NGEM), sedangkan variabel independen (LEV, OSHIP, ROA, AUDCIND, AUDCEXP, AUDCSIZE, AUDCMEET, AUDCREPORT, dan DCHANGE) merupakan campuran antara variabel kontinyu (data metrik) dan kategorial (data non metrik). Campuran skala pada variabel bebas tersebut menyebabkan asumsi multivariate normal distribution tidak dapat terpenuhi, dengan demikian bentuk fungsinya menjadi logistik dan tidak membutuhkan asumsi normalitas dan uji asumsi klasik pada variabel bebasnya (independen) (Ghozali 2011).

\section{HASIL DAN PEMBAHASAN}

\section{Statistik Deskriptif Manajemen Laba Non GAAP dan Pengujian Hipotesis}

Statistik deskriptif dapat dilihat pada Tabel 1. Hasil pengujian hipotesis penelitian dengan menggunakan uji regresi logistik. Sebelum melakukan uji hipotesis, terlebih dahulu 
dilakukan uji Binary Logistic untuk menilai kelayakan model (Goodness Of Fit Test). Hasil uji dapat dilihat pada Tabel 2.

Nilai sig yang dihasilkan adalah sebesar 0,473>0,05, dalam hal ini tidak terdapat perbedaan yang nyata antara klasifikasi yang diamati dengan klasifikasi yang diprediksi atau dengan kata lain model binary logistic cocok untuk dipakai pada analisis selanjutnya. Berdasarkan tabel Hosmer dan Lemeshow Test, terdapat nilai signifikan sebesar 0,473 yang artinya $47,3 \%$ varibel dependen mempengaruh variabel independen dan $52,7 \%$ variable independen dipengaruhi oleh variabel lain yang tidak dijelaskan pada penelitian ini.
Untuk menilai kelayakan keseluruhan model, dilakukan uji Overall Fit Model Test dengan hasil yang tertera pada tabel 4.4. Uji regresi logistik yang selanjutnya menggunakan uji -2 Log Likelihood. Uji ini digunakan untuk menilai model regresi logistic layak dipakai atau tidak. Tampilan output SPSS memberikan dua nilai -2 Log Likelihood yaitu untuk model yang hanya memasukkan konstanta dan untuk model dengan konstanta dan variabel independen ke dalam model regresi logistik. Hasil pengolahan data SPSS uji -2 Log Likelihood dapat dilihat pada tabel 3 dan tabel 4.

Tabel 1: Statistik Deskriptif

\begin{tabular}{lrrrrr}
\hline & N & Minimum & Maximum & Mean & Std Deviation \\
\hline NGEM & 168 & 0 & 1 & 0,21 & 0,412 \\
LEV & 168 & 0,006 & 1,086 & 0,45683 & 0,231495 \\
OSHIP & 168 & 0 & 13,33 & 1,014 & 2,632 \\
ROA & 168 & $-1,1$ & 0,956 & 0,04123 & 0,150419 \\
AUDCIND & 168 & 0 & 1 & 0,51 & 0,501 \\
AUDCEXP & 168 & 0 & 1 & 0,79 & 0,412 \\
AUDCSIZE & 168 & 0 & 1 & 0,95 & 0,226 \\
AUDCMEET & 168 & 0 & 1 & 0,74 & 0,438 \\
AUDREPORT & 168 & 0 & 1 & 0,93 & 0,248 \\
DCHANGE & 168 & 0 & 1 & 0,22 & 0,416 \\
BTD & 168 & $-0,1$ & 0,19 & 0,01592 & 0,023781 \\
BIG 4 & 168 & 0 & 1 & 0,36 & 0,481 \\
LN_SIZE & 168 & 23,39 & 33 & 28,431 & 2,04412 \\
Valid N (listwise) & 168 & & & & \\
\hline
\end{tabular}

Tabel 2: Goodness Of Fit Test

\begin{tabular}{|c|c|c|c|c|c|}
\hline Step & & & Df & & \\
\hline & 1 & 7,608 & & 8 & 0,473 \\
\hline
\end{tabular}

Tabel 3: Iteration History

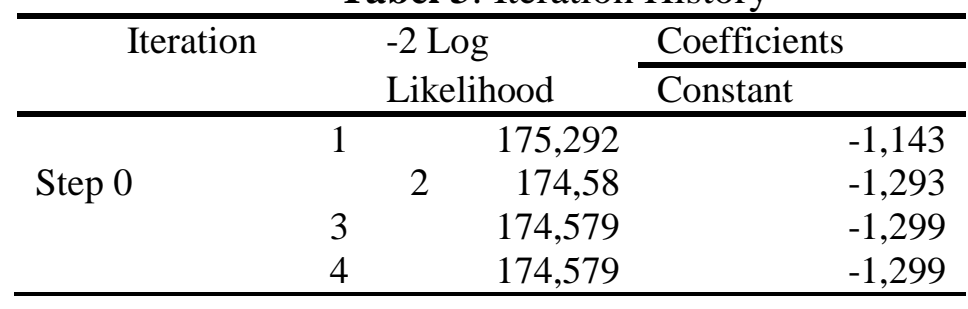

Tabel 4: Model Summary

\begin{tabular}{cccc}
\hline Step & -2 Log & Cox \& Snell & Nagelkerke R \\
& Likelihood & R square & Square \\
1 & $157,628 \mathrm{a}$ & 0,096 & 0,149 \\
\hline
\end{tabular}


Tabel 5: Variables In The Equation

\begin{tabular}{rrrrrrrr}
\hline & \multicolumn{1}{c}{ B } & \multicolumn{1}{c}{ S.E. } & Wald & df & \multicolumn{1}{l}{ Sig. } & Exp(B) \\
\hline LEV & $-0,377$ & 0,958 & 0,155 & 1 & 0,694 & 0,686 \\
OSHIP & $-0,09$ & 0,09 & 0,985 & 1 & 0,321 & 0,914 \\
ROA & 0,625 & 1,368 & 0,209 & 1 & 0,648 & 1,867 \\
ep 1a AUDCIND & $-1,241$ & 0,471 & 6,934 & 1 & 0,008 & 0,289 \\
& AUDCEXP & $-0,105$ & 0,518 & 0,041 & 1 & 0,839 & 0,9 \\
& AUDCSIZE & 0,87 & 1,145 & 0,577 & 1 & 0,447 & 2,387 \\
& AUDMEET & 0,689 & 0,535 & 1,66 & 1 & 0,198 & 1,992 \\
& DCREPORT & $-0,61$ & 0,73 & 0,699 & 1 & 0,403 & 0,543 \\
& DCHANGE & 0,899 & 0,447 & 4,033 & 1 & 0,045 & 2,456 \\
BTD & 0,956 & 8,989 & 0,011 & 1 & 0,915 & 2,602 \\
BIG4 & $-0,471$ & 0,516 & 0,834 & 1 & 0,361 & 0,624 \\
& LN_SIZE & 0,063 & 0,136 & 0,214 & 1 & 0,644 & 1,065 \\
Constant & $-3,114$ & 3,856 & 0,652 & 1 & 0,419 & 0,044 \\
\hline
\end{tabular}

Tabel 3 dan Tabel 4 menunjukan hasil bahwa model fit dengan data yang artinya model tersebut merupakan model regresi yang baik dan melalui penambahan variable independen ke dalam model memperbaiki model fit. Setelah pengujian -2 Log Likelihood selesai, selanjutnya akan diuji dengan uji Nagelkerke $R$ Square. Uji ini dilakukan untuk menilai seberapa besar variasi dari variabel dependen dapat dijelaskan oleh variable independen (Ghozali 2011). Dasar pengambilan hasil dalam uji Nagelkerke $R$ Square dapat dilihat pada nilai Nagelkerke $R$ Square dalam Tabel 4. Terdapat nilai Nagelkerke $R$ Square senilai 0,149 atau $14,9 \%$ yang artinya variabel dependen (manajemen laba Non GAAP) pada penelitian ini mampu dijelaskan oleh variabel independen sebesar $14,9 \%$. Sisanya yaitu sebesar $85,1 \%$ dijelaskan oleh variabel lain di luar model penelitian ini.

\section{Analisis Binary Logistic}

Pengujian hipotesis dalam regresi logistik dilakukan dengan memasukkan seluruh variabel. Pengujian ini bertujuan untuk melihat pengaruh leverage, kepemilikan manajerial, ROA, komite audit independen, keahlian komite audit di bidang keuangan, jumlah anggota komite audit, jumlah pertemuan antar anggota komite audit, opini audit, dan perubahan direksi terhadap manajemen laba Non GAAP. Pengujian ini dilakukan dengan menggunakan enter dengan tingkat signifikan sebesar $5 \%$.
Dasar pengambilan keputusannya adalah apabila nilai signifikansi $>0,05$ maka $\mathrm{Ha}$ ditolak sedangkan jika nilai signifikansi $<0,05$ maka Ha diterima (Ghozali 2011). Hasil pengujian tersebut dapat dilihat pada tabel 5 .

Tabel 5 menunjukan Sig leverage sebesar 0,694>0,05 yang artinya leverage tidak berpengaruh secara statistik terhadap manajemen laba Non GAAP, maka H1a ditolak. Nilai Sig kepemilikan manajerial sebesar 0,321 >0,05 artinya kepemilikan manajerial tidak berpengaruh secara statistik terhadap manajemen laba Non GAAP, maka H1b ditolak. Nilai Sig ROA sebesar 0,648 > 0,05 artinya ROA tidak berpengaruh secara statistik terhadap manajemen laba Non GAAP, maka H1c ditolak. Nilai Sig komite audit independen sebesa $0,008<0,05$ artinya komite audit independen memiliki pengaruh secara statistic terhadap manajemen laba Non GAAP, maka H2a diterima. Nilai Sig keahlian komite audit di bidang keuangan sebesar $0,839>0,05$ artinya keahlian komite audit di bidang keuangan tidak berpengaruh secara statistik terhadap manajemen laba Non GAAP, maka H2b ditolak. Nilai Sig ukuran komite audit sebesar 0,447 >0,05 artinya jumlah anggota komite audit tidak berpengaruh secara statistik terhadap manajemen laba Non GAAP, maka H2c ditolak. Nilai Sig jumlah pertemuan antar anggota komite audit sebesar $0,198>0,05$ artinya jumlah pertemuan antar anggota komite audit tidak berpengaruh secara 
statistic terhadap manajemen laba Non GAAP, maka H2d ditolak. Nilai Sig opini audit sebesar 0,403 >0,05 artinya opini audit tidak berpengaruh secara statistik terhadap manajemen laba Non GAAP, maka H3 ditolak. Nilai Sig perubahan direksi sebesar 0,045 < 0,05 artinya perubahan direksi memiliki pengaruh secara statistik terhadap manajemen laba Non GAAP, maka H4 diterima.

\section{Pembahasan Hasil Penelitian}

\section{Tekanan dan Manajemen Laba Non GAAP}

Variabel tekanan dalam penelitian ini diproksikan dengan leverage, kepemilikan manajerial dan ROA. Leverage, kepemilikan manajerial dan ROA tidak berpengaruh terhadap manajemen laba Non GAAP pada perusahaan yang menyajikan kembali (restatement) laporan keuangan. Sehingga (H1a, H1b, dan H1c) ditolak. Dari hasil uji Statistik deskriptif dapat disimpulkan bahwa rata-rata perusahaan yang menyajikan kembali (restatement) laporan keuangan memiliki leverage yang aman dalam arti perusahaan mampu membayar hutang yang digunakan untuk membiayai aset perusahaan, kepemilikan manajerial juga sangat kecil dengan rata-rata di bawah 5\%, dan ROA yang dihasilkan perusahaan relative rendah. Sehingga manajer tidak termotivasi dan merasa tertekan untuk melakukan praktik manajemen laba Non GAAP.

\section{Kesempatan Terhadap Manajemen Laba Non GAAP}

Variabel kesempatan dalam penelitian ini diproksikan dengan komite audit independen, keahlian komite audit di bidang keuangan, jumlah anggota komite audit, dan jumlah pertemuan antar komite audit. Pada penelitian ini variabel kesempatan yang diproksikan dengan komite audit berpengaruh negatif terhadap manajemen laba Non GAAP. Sehingga (H1a) diterima, sedangkan hipotesis lainnya untuk variabel kesempatan ditolak. Independensi komite audit merupakan hal terpenting yang harus dimiliki oleh anggota komite audit. Kinerja komite audit menjadi efektif jika para anggotanya memiliki independensi dalam menyatakan sikap dan pendapatnya. Hal ini juga dapat dijelaskan karena semakin banyak jumlah komite audit independen dalam perusahaan, maka akan semakin kecil potensi terjadinya manajemen laba Non-GAAP karena pengawasan dari pihak yang independen dapat menjamin manajemen melakukan tugasnya dengan baik.

\section{Rasionalisasi Terhadap Manajemen Laba Non GAAP}

Variabel rasionalisasi dalam penelitian ini diproksikan dengan opini audit. Opini audit tidak berpengaruh terhadap manajemen laba Non GAAP. Sehingga H3 ditolak. Hal ini disebabkan karena terdapat berbagai macam peristiwa atau kejadian yang menyebabkan opini audit mendapatkan opini selain unqualified sehingga bukan hanya karena terjadinya manajemen laba Non GAAP dimana manajemen merasionalisasikan perbuatannya yang menyebabkan opini audit mendapatkan opini selain unqualified.

\section{Kapabilitas Terhadap Manajemen Laba Non GAAP}

Variabel kapabilitas dalam penelitian ini diproksikan dengan perubahan direksi. Perubahan direksi berpengaruh terhadap manajemen laba Non GAAP. Sehingga (H4) diterima. Hal ini disebabkan karena perubahan direksi umumnya sarat dengan muatan politis dan kepentingan pihak-pihak tertentu yang memicu munculnya conflict of interest. Conflict of interest terjadi karena timbulnya ketidakseimbangan informasi (asymmetric information) antara agen (manajer) dengan pihak prisipal. Sehingga semakin tingginya asymmetric information antara agen (manajer) dengan prinsipal (pemilik), mndorong meningkatnya tindakan manajemen laba Non GAAP oleh manajemen.

\section{SIMPULAN}

Penelitian ini bertujuan untuk menguji determinan managemen laba non-GAAP dari perspektif Fraud Diamond Theory (FDT), yang 
pada awalnya digunakan dalam bidang pengauditan untuk menjelaskan mengapa kecurangan dalam laporan keuangan dapat terjadi yang dilihat dari empat elemen yaitu (1) tekanan/motif manajemen, (2) kesempatan, (3) rasionalisasi, dan (4) kapabilitas. Hasil penelitian menunjukkan bahwa tekanan dan rasionalisasi tidak berpengaruh signifikan secara statistik sedangkan kesempatan dan kapabilitas memiliki pengaruh yang signifkan secara statistik. Berpengaruhnya kesempatan dan kapabilitas ini menunjukkan bahwa pentingnya peran dari komite audit independen dalam memastikan bahwa pengandalian internal di perusahaan berjalan baik sehingga manajemen laba non-GAAP dapat diminimalisir. Hal yang sama juga sejalan dengan kapabilitas. Ketika terbuka kesempatan untuk melakukan manajemen laba non GAAP, maka situasi ini akan memotovasi manajer untuk melakukan manajemen laba. Karena itu, kesempatan berupa pergantian atau perubahan direksi harus diwaspadai oleh semua pihak dan regulator. Regulasi yang ketat atas perubahan susunan dewan direksi pada perusahaan perliu dibuat demi mencegahnya muncul kesempatan dilakukannya perilaku opportunistic.

Penelitian selanjutnya diharapkan dapat menambah proksi dari fraud diamond agar cakupan variabel penelitian menjadi lebih luas. Penelitian selanjutnya diharapkan dapat menemukan proksi y ang tepat untuk tekanan dan rasionalisasi pada fraud diamond yang dapat menyebabkan manajemen laba Non GAAP terjadi.

\section{DAFTAR REFERENSI}

Abbott, L. J., S. Parker, dan G. F. Peters. 2004. Audit committee characteristics and restatements. Auditing: A Journal of Practice and Theory 23 (1): 69-87.

Achmad, K., I. Subekti, dan S. Atmini. 2007. Investigasi motivasi dan strategi manajemen laba pada perusahaan publik di Indonesia. Simposium Nasional Akuntansi X, Makassar.
Aghghaleh, S. F., Z. M. Mohamed, dan A. Ahmad. 2014. The effect of personal and organizational factors and role ambiguity amongst internal auditors. International Journal of Auditing 18 (2): 105-114.

Agustia, D. 2013. Pengaruh faktor good corporate governance, free cash flow, dan leverage terhadap manajemen laba. Jurnal Akuntansi dan Keuangan 15 (1): 27-42.

Badertscher, B. A. 2011. Overvaluation and the choice of alternative earnings management mechanisms. The Accounting Review. 86 (5): 1491-1518.

Budiasih, I. G. A. N. 2009. Faktor-faktor yang mempengaruhi praktik perataan laba. Jurnal Akuntansi dan Bisnis 4 (1): 4450.

Blue Ribbon Committee (BRC). 1999. Report and recommendations of the Blue Ribbon Committee on improving the effectiveness of corporate audit committees.

http://www.chugachelectric.com/pdfs/ag enda/fcagenda_051403_ixd.pdf (diakses 7 Januari 2015).

Carlsn, S., dan C. Bathala. 1997. Ownership differences and firm's income smoothing behaviour. Journal of Business and Accounting 24 (2): 179-196.

Choi, J., K. Jeon, dan J. Park. 2004. The role of audit committees in decreasing earnings management: Korean evidence. International Journal of Accounting, Auditing, and Performance Evaluation 1 (1): 37-60.

Cressey, D. 1953. Other people's money: a study in the social psychology of embezzlement. Glancoe: Free Press.

Dechow, P. M., R. G. Sloan, dan A. P. Sweeney. 1996. Causes and consequences of earnings manipulations: An analysis of firms subject to enforcement actions by the SEC. Contemporary Accounting 
Research 13 (1): 1-36.

Dendawijaya, L. 2005. Manajemen Perbankan. Bogor: Ghalia Indonesia.

Francis, J. R., dan J. Krishnan. 1999. Accounting accruals and auditor reporting conservatism. Contemporary Acconting Research 16 (1): 135-165.

Gagola, K. 2011. Analisis faktor risiko yang mempengaruhi kecenderungan kecurangan pelaporan keuangan perusahaan publik di Indonesia. Tesis. Fakultas Ekonomika dan Bisnis, Universitas Diponogoro.

Ghozali, I. 2011. Aplikasi analisis multivariate dengan program IMB SPSS 19. Semarang: Universitas Diponegoro.

Healy, P. M., dan J.M. Wahlen. 1999. A review of the earnings management literature and its implications for standard setting. Accounting Horizons 13 (4): 365-383.

Kompas.com. dipublikasi 23 Juli 2010.

Moeller. 2009. Brink's modern internal auditing, 7th edition. New Jersey: John Wiley \& Sons.

Pamudji, S., dan A. Trihartati. 2008). Pengaruh independen dan efektivitas komite audit terhadap manajemen laba (Studi empiris pada perusahaan manufaktur yang terdaftar di BEI. Jurnal Akuntansi dan Auditing 6 (1).

Price Water House Coopers (PWC). 2003. Building a strategic internal audit fuction.

https://www.pwc.be/en/systemsprocess-assurance/pwc-strategicinternal-audit.pdf (diakses 10 Januari 2015).

Rahman, R. A., dan F. H. M. Ali. 2006. Board, audit committee, culture and earnings management: Malaysian evidence. Managerial Auditing Journal 21 (7): 783-804.
Rahmanti, M. M. 2013. Pendektesian kecurangan laporan keuangan melalui faktor risiko tekanan dan peluang (Studi kasus pada perusahaan yang mendapat sanksi dari Bapepam periode 2002-2006). Skripsi, Universitas Diponegoro.

Rezaee, Z. 2002. Financial statement fraud: Prevention and detection. New York: John Wiley \& Sons.

Rustendi, T. 2009. Analisis terhadap faktor pemicu terjadinya fraud (Suatu kajian teoritis bagi kepentingan audit internal. Jurnal Akuntansi 4 (2): 705-714.

Sam'ani. (2008). Pengaruh good corporate governance dan leverage terhadap kinerja keuangan pada perbankan yang terdaftar di Bursa Efek Indonesia (BEI) tahun 2004-2007. Tesis, Universitas Diponegoro.

Scott, W. R. 2012. Financial accounting theory, $6{ }^{\text {th }}$ Edition. Prentice Hall.

Skousen, C. J., K. R. Smith, dan C. J. Wright. 200). Detecting and predecting financial statement fraud: The effectiveness of the fraud triangle and SAS No. 99.Corporate Governance and Firm Performance Advances in Financial Economic 13: 53-81.

Stice, E. K., J. D. Stice, dan K. F. Skousen. 2004. Akuntansi intermediate. Jakarta: Salemba Empat.

Sugiyono. 2013. Metode penelitian pendidikan (Pendekatan kuantitatif, kualitatif, dan $R \& D)$. Bandung: Alfabeta.

Sugiyono. 2013. Statistika untuk penelitian. Bandung: Alfabeta.

Turner, J. L., T. J. Mock, dan R. P. Sripastava. 2003. An analysis of the fraud triangle. http://citeseerx.ist.psu.edu/viewdoc/do wnload;jsessionid=4D3ADAE4C 3472 FD1BD2D2AC2818DFDF4?doi=10.1. $1.101 .4380 \&$ rep $=$ rep $1 \&$ type $=$ pdf (diakses 2 Februari 2015). 
Ujiyanho, M.A., dan B.A. Pramuka. 2007. Mekanisme corporate governance, manajemen laba dan kinerja keuangan. Simposium Nasional Akuntansi X, Makassar.

Wardhani, R. 2006. Mekanisme corporate governance dalam perusahaan yang mengalami permasalahan keuangan (Financially distressed firms). Simposium Nasional Akuntansi IX, Padang.

Widyaningsih. A. U. 2001. Analisis faktorfaktor yang berpengaruh terhadap earnings management pada perusahaan go public di Indonesia. Jurnal Akuntansi \& Keuangan 3 (2): 89-101.

Wolfe, D. T., dan D R. Hermanson. 2004. The fraud diamond: Considering the four elements of fraud. The CPA Journal: 38-42.

Xie, B., W. N. Davidson, dan P. J. DaDalt. 2003. Earnings management and corporate governance: The role of board and the audit committee. Journal of Corporate Finance 9 (3): 295-316. 